\title{
THE SEGREGATION PATTERNS AND FERTILITY OF SHEEP HETEROZYGOUS AND HOMOZYGOUS FOR THREE DIFFERENT ROBERTSONIAN TRANSLOCATIONS
}

\author{
A. N. BRUÈRE \\ Department of Veterinary Clinical Science, \\ Massey University, New Zealand
}

(Received 15th May 1974)

\begin{abstract}
Summary. A series of mating experiments using sheep bearing three different Robertsonian translocations, $t_{1}, t_{2}$ and $t_{3}$, are described. All three translocations proved familial. Rams which were heterozygous or homozygous for each of the translocations, when mated to ewes of normal karyotype, usually produced the expected ratios of progeny for each chromosome category. The irregular segregation patterns recorded in three instances are discussed.

The fertility of matings between translocation-bearing rams and normal ewes was equivalent to, or better than, that of matings of other Romney flocks at Massey University, and equivalent to National Romney fertility data. Between $78.95 \%$ and $89.24 \%$ of ewes conceived to one service, which indicated that although translocation heterozygous rams produce abnormal numbers of aneuploid secondary spermatocytes, these apparently do not mature to fertile spermatozoa as in the tobacco mouse.

The $t_{1} \times t_{1}$ matings in particular and $t \times t$ matings in general produced a significantly lower lambing percentage than either $t$ ram or $t$ t $\operatorname{ram} x$ normal ewe matings. This was due to a significant increase in dry ewe numbers in the former category, and factors which may have caused this fertility reduction are discussed. Three different types of double translocation heterozygotes of sheep were bred and are described for the first time.
\end{abstract}

\section{INTRODUCTION}

In previous reports, three different Robertsonian translocations of sheep have been described (Bruère, 1969, 1973; Bruère \& Mills, 1971; Bruère, Chapman \& Wyllie, 1972; Bruère \& Chapman, 1974; Bruère, Zartman \& Chapman, 1974). The effects of similar translocations on the fertility of domestic animals and man have been discussed by many authors, but the paucity of pedigree and mating data prevented any useful conclusion.

In this report, mating experiments conducted between 1969 and 1973 with sheep carrying these translocations individually, either in the hetero- 
zygous or the homozygous state, are described and the segregation patterns determined from the chromosomal analysis of the progeny are discussed. An analysis of the reproductive performance of these sheep is also presented.

\section{MATERIALS AND METHODS}

\section{Terminology}

Previously, the three translocations have been described as Massey I, II and III (M I, M II and M III). Since the chromosomes of each are now identified (Bruère et al., 1974) and are non-homologous, a change in terminology has been made which is a modification based on the system recommended for human chromosomes at the Paris Conference (1971) on standardization in human cytogenetics. This has been done to prevent confusion with the

Table 1. Summary of various translocation mating groups (1969-73) showing numbers of Romney ewes mated and lambs analysed chromosomally

\begin{tabular}{|c|c|c|c|}
\hline \multicolumn{2}{|c|}{ Karyotypes of mating categories } & \multirow{2}{*}{$\begin{array}{c}\text { No. of ewes } \\
\text { mated }\end{array}$} & \multirow{2}{*}{$\begin{array}{l}\text { No. of lambs } \\
\text { analysed } \\
\text { chromosomally }\end{array}$} \\
\hline Rams & Ewes & & \\
\hline \multirow[t]{2}{*}{$\begin{array}{l}\text { (M I) } 53, x y, t_{1} \\
\text { (M II) } 53, x y, t_{2} \\
\text { (M III) } 52, x y, t_{3} t_{3} \\
\text { (M I) } 52, x y, t_{1} t_{1} \\
\text { *M I, M III) } 52, x y, t_{1} t_{3} \\
\text { (M I) } 53, x y, t_{1} \\
\text { (M I) } 53, x y, t_{1} \\
\text { (M II) } 52, x y, t_{2} t_{2} \\
\text { (M II) } 52, x y, t_{2} t_{2} \\
\text { (M III) } 52, x y, t_{3} t_{3} \\
\text { (M III) } 52, x y, t_{3} t_{3} \\
\text { (M III) } 52, x y, t_{3} t_{3}\end{array}$} & 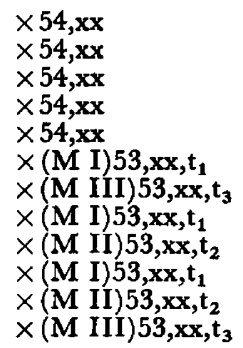 & $\begin{array}{r}185 \\
128 \\
18 \\
49 \\
10 \\
107 \\
20 \\
25 \\
4 \\
23 \\
6 \\
22\end{array}$ & $\begin{array}{r}271 \\
130 \\
27 \\
63 \\
14 \\
71 \\
18 \\
26 \\
4 \\
12 \\
6 \\
18\end{array}$ \\
\hline & & 597 & 660 \\
\hline
\end{tabular}

* Bruère \& Chapman (1974).

terms metaphase I and metaphase II used when discussing meiotic chromosomes. Both previous and present terminology are used in Table 1. The previously used + sign has been excluded after $t$, the symbol for a translocation.

\section{Animals}

The $53, \mathrm{t}_{1}$ and $52, \mathrm{t}_{1} \mathrm{t}_{1}$ sheep were produced by mating one of the original rams, M236/67 (Bruère, 1969), to unrelated Romney ewes of normal karyotype $(2 n=54)$. In addition, eight heterozygous ewes $\left(53, \mathbf{x x}, \mathrm{t}_{1}\right)$ were purchased from the same sheep stud as Ram M236/67. The 53,t $t_{2}$ sheep were either bred by mating a ram produced by one of the original ewes found with this translocation or were donated from an experimental Romney breeding flock, belonging to Massey University, where sheep with this translocation had been found. 
The 53, $t_{3}$ and $52, t_{3} t_{3}$ Drysdale sheep were either purchased from one of the main Drysdale studs (Bruère et al., 1972) or bred by mating a Drysdale ram $\left(52, \mathrm{xy}, \mathrm{t}_{3} \mathrm{t}_{3}\right)$ to Romney ewes.

All lambs and ewes were identified with a metal ear-tag which had a serial number and year of birth. In addition, during mating and lambing the ewes carried an identification tag around their neck which corresponded to the eartag number. All sheep were grazed on the one farm and were maintained as uniformly as possible. The rams used in these experiments were free from brucellosis. During the mating period, the rams were harnessed with a tupping raddle. The colour of the raddle was changed every 14 to 15 days and the rams were kept with the ewes for four to six oestrous cycles. The twelve different mating categories are listed in Table 1, together with the numbers of ewes mated and the number of progeny produced and analysed chromosomally.

For the comparison of the reproductive performance of the various mating groups (Tables 5 to 8 ), criteria of reproductive efficiency similar to those of Turner (1969) were used. The number of ewes mating but not producing a lamb (dry ewes, $E_{D M}$ ) compared with the number of ewes mated and giving birth to young $\left(E_{M}\right)$ was used as a measure of conception and embryonic survival. The difference between the number of lambs born $\left(\mathrm{L}_{\mathrm{BM}}\right)$ and the number

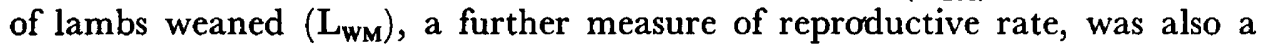
useful indicator of inbreeding (Doney, 1966; Lax \& Brown, 1968).

During lambing, the ewes were under regular care during the day and were checked between 23.00 and 24.00 hours each night. Ear tags were attached to lambs immediately after birth so that no errors of identification occurred. The cause of deàth of all premature and dead lambs was established at autopsy, when possible.

\section{Cytogenetic methods}

The karyotypes of a total of 1050 animals were examined. This number included 390 ewes of normal karyotype (used in the various matings) and 660 of the progeny. Some of the latter were also used in the mating experiments.

A routine whole blood leucocyte culture technique and the usual form of chromosome preparation was used for the chromosome examinations (Bruère \& McLaren, 1967). Lambs were bled and their karyotypes were determined, usually within a week of birth. A system of double checking of all samples from collection to karyotyping was used and random double checks on the karyotypes of some lambs were carried out. None of these gave conflicting results. The chromosomes of several lambs that were born dead were analysed from cells obtained from fibroblast cultures.

\section{RESULTS}

The segregation patterns of translocation heterozygous rams $(53, x y, t)$ mated with normal ewes $(54, x \mathbf{x})$ are summarized in Table 2 , and those for the intermating of heterozygotes and homozygotes (ewes and rams) are summarized in Tables 3 and 4. In Table 2, the accumulated data for both the 53, $t_{1}$ and $53, t_{2}$ gave a regular segregation pattern of $1: 1: 1: 1$. More than expected 
Table 2. Numbers and sex of progeny with 54 and 53 chromosomes from Romney sheep matings: (a) $53, \mathrm{xy}, \mathrm{t}_{\mathbf{1}} \times 54, \mathrm{xx}$ and (b) $53, \mathrm{xy}, \mathrm{t}_{2} \times$ $54, \mathrm{xx}$

\begin{tabular}{|c|c|c|c|c|c|c|c|}
\hline \multicolumn{2}{|r|}{ Matings } & rear & \multicolumn{4}{|c|}{ Chromosome number and sex } & Total \\
\hline \multirow[t]{3}{*}{ (a) } & \multirow[t]{3}{*}{$\begin{array}{l}53, \mathrm{xy}, \mathrm{t}_{1} \\
\times \\
54, \mathrm{xx}\end{array}$} & $\begin{array}{l}1969 \\
1970 \\
1971 \\
1972\end{array}$ & $\begin{array}{r}28 \\
9 \\
19 \\
11\end{array}$ & $\begin{array}{r}23 \\
10 \\
35 \\
4\end{array}$ & $\begin{array}{l}16 \\
10 \\
25 \\
12\end{array}$ & $\begin{array}{r}22 \\
10 \\
29 \\
8\end{array}$ & $\begin{array}{r}89 \\
39 \\
108 \\
35\end{array}$ \\
\hline & & Total & 67 & 72 & 63 & 69 & 271 \\
\hline & & \multicolumn{5}{|c|}{$\begin{array}{l}\chi^{2} \text { analysis for heterogeneity between years gave a } \\
\text { non-significant value. The pooled data do not differ } \\
\text { significantly from the expected ratio of } 1: 1: 1: 1 \text {. }\end{array}$} & \\
\hline \multirow[t]{3}{*}{ (b) } & \multirow{3}{*}{$\begin{array}{l}53, \mathbf{x y}, \mathrm{t}_{2} \\
\times \\
54, \mathbf{x x}\end{array}$} & $\begin{array}{l}1972 \\
1973\end{array}$ & $\begin{array}{l}16 \\
14\end{array}$ & $\begin{array}{l}15 \\
25\end{array}$ & $\begin{array}{l}22 \\
16\end{array}$ & $\begin{array}{r}9 \\
13\end{array}$ & $\begin{array}{l}62 \\
68\end{array}$ \\
\hline & & Total & 30 & 40 & 38 & 22 & 130 \\
\hline & & \multicolumn{6}{|c|}{$\begin{array}{l}\chi^{2} \text { analysis for heterogeneity of the pooled data was } \\
\text { significant at } P<0.05 \text {. } \\
\chi_{1}^{2} \text { between } 54, \mathrm{xx} \text { and } 53, \mathrm{xx}, \mathrm{t}(1972)=4.64 ; P< \\
0.05 \text {. }\end{array}$} \\
\hline
\end{tabular}

Table 3. Numbers and sex of progeny with 52,53 , and 54 chromosomes from Romney sheep matings: (a) $53, \mathrm{xy}, \mathrm{t}_{1} \times 53, \mathrm{xx}, \mathrm{t}_{1}$ and (b) $53, x y, t_{1} \times 53, x^{2}, t_{3}{ }^{*}$

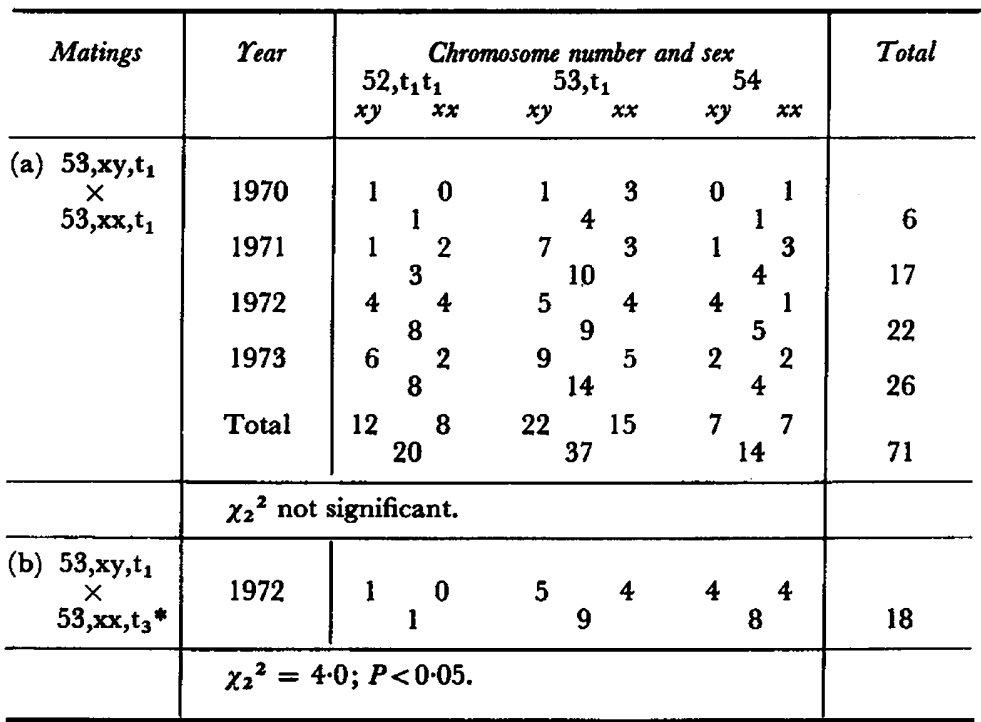

* Expected ratio $1: 2: 1$. 
numbers of $53, x y, t_{1}$ progeny were born in 1971 (Table $2 a$ ) and similarly there was a significant reduction in $53, \mathbf{x x}, \mathrm{t}_{2}$ born in 1972 (Table $2 \mathrm{~b}$ ). The pooled data in the latter matings gave a significant value for heterogeneity between years. As expected, all progeny from the mating of homozygous rams $\left(52, x y, t_{1} t_{1}\right.$ and $52, x y, t_{3} t_{3}$ ) with normal ewes, were translocation heterozygotes and there were no significant deviations in sex ratios.

In Table $3(a)$, the mating of $53, x y, t_{1}$ and $53, x x, t_{1}$ produced the expected numbers of progeny with 52,53 and 54 chromosomes, and although these varied between years, the overall expected ratio of $1: 2: 1$ was produced. The data in Tables 2(a) and 3(a) confirm that the $t_{1}$ chromosome segregates alternately. In Table 3(b), a deficiency in the number of progeny with 52 chromosomes was recorded. While this deficiency was significant, the numbers

Table 4. Numbers and sex of progeny with 52 and 53 chromosomes from Romney sheep matings: (a) $52, \mathrm{xy}, \mathrm{t}_{2} \mathrm{t}_{2} \times$ $53, x x, t_{1}$, (b) $52, x y, t_{3} t_{3} \times 53, x x, t_{1}$, and (c) $52, x y, t_{3} t_{3} \times 53, x x, t_{3}$

\begin{tabular}{|c|c|c|c|c|}
\hline Matings & $\begin{array}{rr} & \text { Chromosome } \\
52, \mathrm{xy}, \mathrm{t} & 52, \mathrm{xx}, \mathrm{t}\end{array}$ & $\begin{array}{c}\text { number and } \\
53, \mathrm{xy}, \mathrm{t}\end{array}$ & $e_{53, x x, t}$ & Total \\
\hline (a) $\begin{aligned} & 52, x y, t_{2} t_{2} \\
& \times 53, x x, t_{1}\end{aligned}$ & 7 & 1 & 11 & 26 \\
\hline & \multicolumn{3}{|c|}{$\chi_{3}^{2}=11.78 ; P<0.0100$} & \\
\hline \multirow[t]{2}{*}{ (b) $\begin{array}{l}5 \\
\times\end{array}$} & 2 & 4 & 3 & 12 \\
\hline & \multicolumn{3}{|c|}{$\chi_{3}{ }^{2}=$ Not significant. } & \\
\hline \multirow[t]{2}{*}{ (c) $\begin{array}{r}52, x y, t_{3} t_{3} \\
\times 53, x x, t_{3}\end{array}$} & 2 & 5 & 4 & 18 \\
\hline & \multicolumn{3}{|c|}{$\chi_{3}^{2}=$ Not significant } & \\
\hline
\end{tabular}

Expected ratios for homozygous males $\times$ heterozygous females was $1: 1: 1: 1$.

involved were limited and repeat matings would be necessary before a conclusion could be reached. This applies also to the deficiency of 53,xy,t and the excess of 53,xx,t in Table 4(a). Otherwise, the expected ratios of progeny were produced in each of the other matings listed in Tables $4(a)$, (b) and (c).

The $53, \mathrm{xy}, \mathrm{t}_{1}$ rams mated to $54, \mathrm{xx}$ ewes repeatedly produced lambing percentages (Table 5a) which were better than comparable matings of other Romney flocks on the University farms and which, in 1969, were above the national average of $133.5 \%$ quoted for Romney stud flocks (Quinlivan \& Martin, 1971a). The numbers of dry ewes were also low, $3.25 \%$ compared to the national average of $6 \%$ (Quinlivan \& Martin, 1971a). Only one premature lamb (Table 7a) was recorded in this group.

The 53,xy, $t_{2}$ rams (in 1972, a ram lamb 8 months of age) mated with normal ewes gave a lower (Table $5 \mathrm{~b}$ ) but still satisfactory number of progeny and a dry ewe number within the normal range for the Romney breed.

The mating of 52,xy,tt homozygous rams (Tables $5 \mathrm{c}$ to $5 \mathrm{~d}$ ) to normal $54, \mathrm{xx}$ ewes in both instances produced high lamb percentages with few dry 
Table 5. Reproductive details of mating translocation Romney rams to ewes of normal karyotype

\begin{tabular}{|c|c|c|c|c|c|c|c|}
\hline Mating category & rear & $\mathbf{E}_{\mathbf{M}}$ & $\mathbf{E}_{\mathrm{DM}}$ & $\mathbf{L}_{\mathbf{B M}}$ & $\mathbf{L}_{\mathbf{W M}}$ & $\% \mathrm{E}_{\mathrm{DM}}$ & $\% \mathrm{~L}_{W M}$ \\
\hline \multirow[t]{2}{*}{$\begin{array}{l}\text { (a) } 53, \mathrm{xy}, \mathrm{t}_{1} \times \\
54, \mathrm{xx}\end{array}$} & $\begin{array}{l}1969 \\
1970 \\
1971 \\
1972\end{array}$ & $\begin{array}{c}57 \\
35 \\
93 \\
\text { Not i }\end{array}$ & $\begin{array}{c}4 \\
1 \\
1 \\
\text { cluded }\end{array}$ & $\begin{array}{c}98 \\
48 \\
120 \\
\text { here be }\end{array}$ & $\begin{array}{c}89 \\
39 \\
106 \\
\text { ause of }\end{array}$ & $\begin{array}{c}7.02 \\
2.86 \\
1.07 \\
\text { Caesarea }\end{array}$ & $\begin{array}{l}156 \cdot 14 \\
111.43^{*} \\
113 \cdot 98 \\
\text { delivery }\end{array}$ \\
\hline & Total & 185 & 6 & 266 & 234 & $3 \cdot 24$ & $126 \cdot 49$ \\
\hline \multirow[t]{2}{*}{ (b) $\begin{array}{l}53, \mathrm{xy}, \mathrm{t}_{2} \times \\
54, \mathbf{x x}\end{array}$} & $\begin{array}{l}1972 \dagger \\
1973\end{array}$ & $\begin{array}{l}57 \\
71\end{array}$ & $\begin{array}{l}5 \\
6\end{array}$ & $\begin{array}{l}68 \\
73\end{array}$ & $\begin{array}{l}59 \\
68\end{array}$ & $\begin{array}{l}8.77 \\
8 \cdot 45\end{array}$ & $\begin{array}{r}103 \cdot 51 \\
95 \cdot 77\end{array}$ \\
\hline & Total & 128 & 11 & 141 & 127 & $8 \cdot 6$ & $99 \cdot 22$ \\
\hline $\begin{array}{l}\text { (c) } 52, \mathrm{xy}, \mathrm{t}_{3} \mathrm{t}_{3} \times \\
54, \mathrm{xx}\end{array}$ & 1971 & 18 & 1 & 28 & 27 & $5 \cdot 5$ & $150 \cdot 0$ \\
\hline $\begin{array}{l}\text { (d) } 52, x y, t_{1} t_{1} \times \\
54, x x\end{array}$ & 1973 & 49 & 一 & 63 & - & - & $128-5 \ddagger$ \\
\hline
\end{tabular}

$\mathbf{E}_{\mathrm{M}}=$ ewes mated and giving birth; $\mathbf{E}_{\mathrm{DM}}=$ ewes dry to ewes mated; $\mathbf{L}_{\mathrm{BM}}=$ lambs born to ewes mated; $\mathrm{L}_{\mathrm{WM}}=$ lambs weaned to ewes mated.

* In this year, a severe storm accounted for four lambs that otherwise would probably have lived.

A ram lamb was used in this mating.

\$ The ewes used in this mating were also used as a Caesarean exercise for students so that no significance could be placed on the dry ewe numbers. Forty-nine ewes gave thirty-seven male and twenty-six female, including twenty-eight twin lambs.

ewes. In summary, the reproductive performance of ewes of normal karyotype mated to $53, x y, t_{1}$ and $52, x y, t_{1} t_{1}$ and $52, x y, t_{3} t_{3}$ rams was comparable to the average performance of New Zealand stud Romneys.

The reproductive results from mating $53, \mathrm{xy}, \mathrm{t}$ and $52, \mathrm{xy}, \mathrm{tt}$ rams to $53, \mathrm{xx}, \mathrm{t}$ ewes are shown in Tables 6(a to e). In Table 6(a), the lambing percentage

Table 6. Reproductive details of mating translocation heterozygous and homozygous Romney rams to translocation heterozygous ewes

\begin{tabular}{|c|c|c|c|c|c|c|c|}
\hline Mating category & rear & $\mathbf{E}_{\mathbf{M}}$ & $\mathbf{E}_{\mathbf{D M}}$ & $\mathrm{L}_{\mathbf{B M}}$ & $\mathbf{L}_{\mathbf{W M}_{M}}$ & $\% \mathbf{E}_{\mathrm{DM}}$ & $\% \mathrm{~L}_{W M}$ \\
\hline \multirow[t]{2}{*}{ (a) $\frac{53, \mathbf{x y}, \mathbf{t}_{\mathbf{t}} \times}{53, \mathbf{x x}, \mathbf{t}_{\mathbf{t}}}$} & $\begin{array}{l}1970 \\
1971 \\
1972 \\
1973\end{array}$ & $\begin{array}{l}19 \\
27 \\
28(21) \\
33\end{array}$ & $\begin{array}{l}13 \\
8 \\
7 \\
9\end{array}$ & $\begin{array}{l}6 \\
19 \\
23(21) \\
27\end{array}$ & $\begin{array}{l}6 \\
17 \\
17(15) \\
27\end{array}$ & $\begin{array}{l}\overline{29 \cdot 63} \\
14 \cdot 29 \\
27 \cdot 27\end{array}$ & $\begin{array}{l}\overline{62} \cdot 96 \\
71 \cdot 43 \\
81 \cdot 82\end{array}$ \\
\hline & Total & $107(81)$ & $37(20)$ & $75(67)$ & $67(59)$ & $24 \cdot 69$ & $72 \cdot 84$ \\
\hline $\begin{array}{l}\text { (b) } 53, x y, t_{1} \times \\
53, x x, t_{3}\end{array}$ & 1972 & $20(12)$ & $4(1)$ & $25(20)$ & $18(15)$ & $8 \cdot 3$ & $125 \cdot 0$ \\
\hline (c) $\begin{array}{l}52, \mathrm{xy}, \mathrm{t}_{2} \mathrm{t}_{2} \times \\
55, \mathrm{xx}, \mathrm{t}_{1}\end{array}$ & 1973 & 22 & 4 & 28 & 25 & $18 \cdot 18$ & 113.64 \\
\hline $\begin{array}{l}\text { (d) } 52, \mathrm{xy}, \mathrm{t}_{3} \mathrm{t}_{3} \times \\
53, \mathbf{x x}, \mathrm{t}_{3}\end{array}$ & 1972 & $23(16)$ & $6(1)$ & $17(15)$ & $10(8)$ & $6 \cdot 25$ & $50 \cdot 0$ \\
\hline $\begin{array}{l}\text { (e) } 52, \mathrm{xy}, \mathrm{t}_{3} \mathrm{t}_{3} \times \\
53, \mathrm{xx}, \mathrm{t}_{3}\end{array}$ & 1973 & 22 & 5 & 21 & 18 & $22 \cdot 73$ & $81 \cdot 82$ \\
\hline
\end{tabular}

Symbols as for Table 5. The number of mature ewes and the progeny of mature ewes are given in parentheses. In 1971 and 1973, mature ewes only were mated. In 1970, only ewe lambs were mated. The percentage figure is based on the mature ewe data only. 
was much lower for this category than the $53, \mathrm{xy}, \mathrm{t}_{\mathbf{1}} \times 54, \mathrm{xx}$ (Table $5 \mathrm{a}$ ) and the dry ewe numbers were significantly higher. Similar trends were seen in the results given in Tables 6(d) and 6(e), but not in those in Tables 6(b) and 6(c). The good lambing percentages recorded in Tables $6(\mathrm{~b})$ and 6(c) were mainly due to the compensatory effects of a high proportion of twin births. The numbers of dry ewes were significantly higher than those resulting from the $53, \mathrm{xy}, \mathrm{t} \times 54, \mathrm{xx}$ matings.

The lamb losses between $53, \mathrm{xy}, \mathrm{t} \times 54, \mathrm{xx}$ and 53 , xy,t and $52, \mathrm{xy}, \mathrm{tt} \times 53, \mathrm{xx}, \mathrm{t}$ were not significantly different (Tables $7 a$ and $b$ ). In neither group was there

Table 7. Lamb losses analysed and compared between (a) translocation rams $x$ normal ewes, and (b) translocation rams $\times$ translocation ewes

(a) Translocation rams $\times$ normal ewes

\begin{tabular}{l|ccc|c|c|c|c}
\hline $\begin{array}{l}\text { Mating } \\
\text { category }\end{array}$ & $\mathrm{E}_{\mathrm{M}}$ & $\mathrm{L}_{\mathrm{B}}$ & $\mathrm{L}_{\mathrm{B}}-\mathrm{L}_{\mathrm{w}}$ & Premature & $\begin{array}{c}\text { Perinatal } \\
\text { death }\end{array}$ & $\begin{array}{c}\text { Perinatal } \\
\text { to } \\
\text { weaning }\end{array}$ & Comments \\
\hline $\begin{array}{l}53, \mathbf{x y}, \mathrm{t}_{\mathbf{1}} \times \\
54, \mathbf{x x}\end{array}$ & 185 & 266 & 32 & 1 & 24 & 7 & $\begin{array}{l}\text { Five lambs } \\
\text { with chorea } \\
\text { destroyed }\end{array}$ \\
\hline $\begin{array}{l}53, \mathbf{x y}, \mathrm{t}_{2} \times \\
54, \mathbf{x x}\end{array}$ & 128 & 141 & 14 & 2 & 8 & 4 & $\begin{array}{l}\text { Two perinatal } \\
\text { deaths due to } \\
\text { ewe with } \\
\text { pregnancy } \\
\text { toxaemia }\end{array}$ \\
\hline $\begin{array}{l}52, \mathrm{xy}, \mathrm{t}_{3} \mathrm{t}_{3} \\
\times 54, \mathbf{x x}\end{array}$ & 18 & 28 & 1 & 0 & 1 & 0 & \\
\hline \begin{tabular}{l} 
Totals* \\
\hline 0
\end{tabular} & 331 & 435 & 47 & 3 & 33 & 11 & \\
\hline
\end{tabular}

* Lambing percentage (a) on lambs born $=131.42 \%$; (b) on lambs weaned $=117 \cdot 22 \%$.

(b) Translocation rams $\times$ translocation ewes

\begin{tabular}{l|ccc|c|c|c|c}
\hline $\begin{array}{l}\text { Mating } \\
\text { category }\end{array}$ & $\mathrm{E}_{\mathrm{M}}$ & $\mathrm{L}_{\mathrm{B}}$ & $\mathrm{L}_{\mathrm{B}}-\mathrm{L}_{\mathrm{W}}$ & Premature & $\begin{array}{c}\text { Perinatal } \\
\text { death }\end{array}$ & $\begin{array}{c}\text { Perinatal } \\
\text { to } \\
\text { weaning }\end{array}$ & Comments \\
\hline $\begin{array}{l}53, \mathrm{xy}, \mathrm{t}_{1} \times \\
53, \mathbf{x x}, \mathrm{t}_{1}\end{array}$ & 81 & 67 & 8 & 2 & 4 & 2 & $\begin{array}{c}\text { Two lambs } \\
\text { with chorea } \\
\text { destroyed }\end{array}$ \\
\hline $\begin{array}{l}53, \mathbf{x y}, \mathrm{t}_{1} \times \\
53, \mathbf{x x}, \mathrm{t}_{3}\end{array}$ & 12 & 20 & 5 & 0 & 5 & 0 & \\
\hline $\begin{array}{l}52, \mathbf{x y}, \mathrm{t}_{2} \mathrm{t}_{2} \\
\times 53, \mathbf{x x}, \mathrm{t}_{1}\end{array}$ & 25 & 28 & 2 & 0 & 2 & 0 & \\
\hline $\begin{array}{l}52, \mathrm{xy}, \mathrm{t}_{3} \mathrm{t}_{3} \\
\times 53, \mathbf{x x}, \mathrm{t}_{1}\end{array}$ & 16 & 15 & 7 & 6 & 1 & 0 & \\
\hline $\begin{array}{l}52, \mathrm{xy}, \mathrm{t}_{3} \mathrm{t}_{3} \\
\times 53, \mathbf{x x}, \mathrm{t}_{3}\end{array}$ & 22 & 21 & 3 & 1 & 2 & 0 & \\
\hline Totals* & 156 & 151 & 25 & 9 & 14 & 2 & \\
\hline
\end{tabular}

Symbols as for Table 5 .

* Lambing percentage (a) on lambs born $=96.79 \%$; (b) on lambs weaned $=80.77 \%$. 
an excess of lambs in any of the three categories, premature, perinatal death, or perinatal death to weaning loss, except in Table $7(\mathrm{~b})$ where $52, \mathrm{xy}, \mathrm{t}_{3} \mathrm{t}_{3} \times$ $53, \mathrm{xx}, \mathrm{t}_{1}$ produced six premature lambs. In this instance, a confirmed case of toxoplasmosis was diagnosed. Since toxoplasmosis occurs sporadically in New Zealand sheep, this could have been the cause of the high number of premature lambs in this group.

It was not possible to reach a definite conclusion on the significance of the difference in dry ewe numbers between the $53, \mathrm{xy}, \mathrm{t} \times 54, \mathrm{xx}$ matings and the $53, \mathrm{xy}, \mathrm{t} \times 53$, $\mathrm{xx}, \mathrm{t}$ matings. The ewes used in the $53, \mathrm{xy}, \mathrm{t} \times 54, \mathrm{xx}$ matings were all more than four years old, while some of the ewes used in the 53,xy,tx $53, \mathrm{xx}, \mathrm{t}$ matings (Table 6) were 18 months and $2 \frac{1}{2}$ years of age (Table 8).

Table 8. Details of age groups of ewes used in translocation $\times$ translocation matings and dry ewes in each category

\begin{tabular}{|c|c|c|c|c|c|c|c|c|c|}
\hline & $\begin{array}{l}\text { Mating } \\
\text { category }\end{array}$ & rear & $\mathbf{E}_{\mathbf{M}}$ & $\begin{array}{l}\text { Aged } \\
\text { ewes }\end{array}$ & Dry & $\begin{array}{l}2 \frac{1}{2}-\text { year- } \\
\text { old } \\
\text { ewes }\end{array}$ & $D r y$ & $\begin{array}{c}\text { 18-month- } \\
\text { old } \\
\text { ewes }\end{array}$ & $D r y$ \\
\hline \multirow[t]{3}{*}{ (a) } & \multirow{3}{*}{$\begin{array}{l}53, x y, t_{1} \times \\
53, x x, t_{1}\end{array}$} & 1970 & & & \multicolumn{2}{|c|}{ All lambs } & & & \\
\hline & & $\begin{array}{l}1971 \\
1972 \\
1973\end{array}$ & $\begin{array}{l}27 \\
21 \\
33\end{array}$ & $\begin{array}{r}8 \\
4 \\
17\end{array}$ & $\begin{array}{l}1 \\
0 \\
1\end{array}$ & $\begin{array}{r}0 \\
10 \\
3\end{array}$ & $\begin{array}{l}0 \\
2 \\
2\end{array}$ & $\begin{array}{r}19 \\
7 \\
13\end{array}$ & $\begin{array}{l}7 \\
1 \\
6\end{array}$ \\
\hline & & Total & 81 & 29 & 2 & 13 & 4 & 39 & 14 \\
\hline (b) & $\begin{array}{l}53, \mathbf{x y}, \mathrm{t}_{1} \times \\
53, \mathbf{x x}, \mathrm{t}_{3}\end{array}$ & 1972 & 12 & 12 & 1 & 0 & 0 & 0 & 0 \\
\hline (c) & $\begin{array}{r}52, \mathrm{xy}, \mathrm{t}_{2} \mathrm{t}_{2} \\
\times 53, \mathrm{xx}, \mathrm{t}_{1}\end{array}$ & 1973 & 22 & 7 & 0 & 5 & 2 & 10 & 2 \\
\hline (d) & $\begin{array}{r}52, \mathrm{xy}, \mathrm{t}_{3} \mathrm{t}_{3} \\
\times 53, \mathrm{xx}, \mathrm{t}_{1}\end{array}$ & 1972 & 16 & 11 & 1 & 0 & 0 & 5 & 0 \\
\hline (e) & $\begin{array}{r}52, \mathrm{xy}, \mathrm{t}_{3} \mathrm{t}_{3} \\
\times 53, \mathrm{xx}, \mathrm{t}_{3}\end{array}$ & 1973 & 22 & 9 & 3 & 0 & 0 & 13 & 2 \\
\hline & tal a to e & & 153 & 68 & 7 & 18 & 6 & 67 & 18 \\
\hline
\end{tabular}

The Table presents the data for mature ewes only.

However, when the 18-month-old and the 21-year-old ewes were not considered in the comparison, no significant differences in dry ewe numbers between these two groups were recorded. When the dry ewe numbers of the aged and $2 \frac{1}{2}$-year-old translocation ewes of the $53, \mathrm{xx}, \mathrm{t}_{1}$ (Table 8a) were compared with those of the $53, x y, t_{1} \times$ normal ewes (Table $5 a$ ), however, a significant difference was recorded $\left(\chi_{1}^{2}=6.28 ; P<0.05\right)$. A significant difference in dry ewe numbers was also obtained by comparing non-translocation aged ewes $\times 53, \mathrm{xy}, \mathrm{t}$ rams (Tables $5 \mathrm{a}, \mathrm{b}$ and $\mathrm{c}$ ) to aged and $2 \frac{1}{2}$-year-old dry ewes (Tables $8 \mathrm{a}$ to e) $\left(\chi_{1}{ }^{2}=7.937 ; P<0.01\right)$. The present data suggest, therefore, that the dry ewe numbers may be increased when translocation rams are mated to translocation ewes, but further matings will be necessary to verify this observation.

As a result of these matings, previously unreported $52, x y, t_{2} t_{2}$ and $52, x x, t_{2} t_{2}$ homozygotes were produced (Pl. 1, Fig. 1). The former ram was phenotypically 


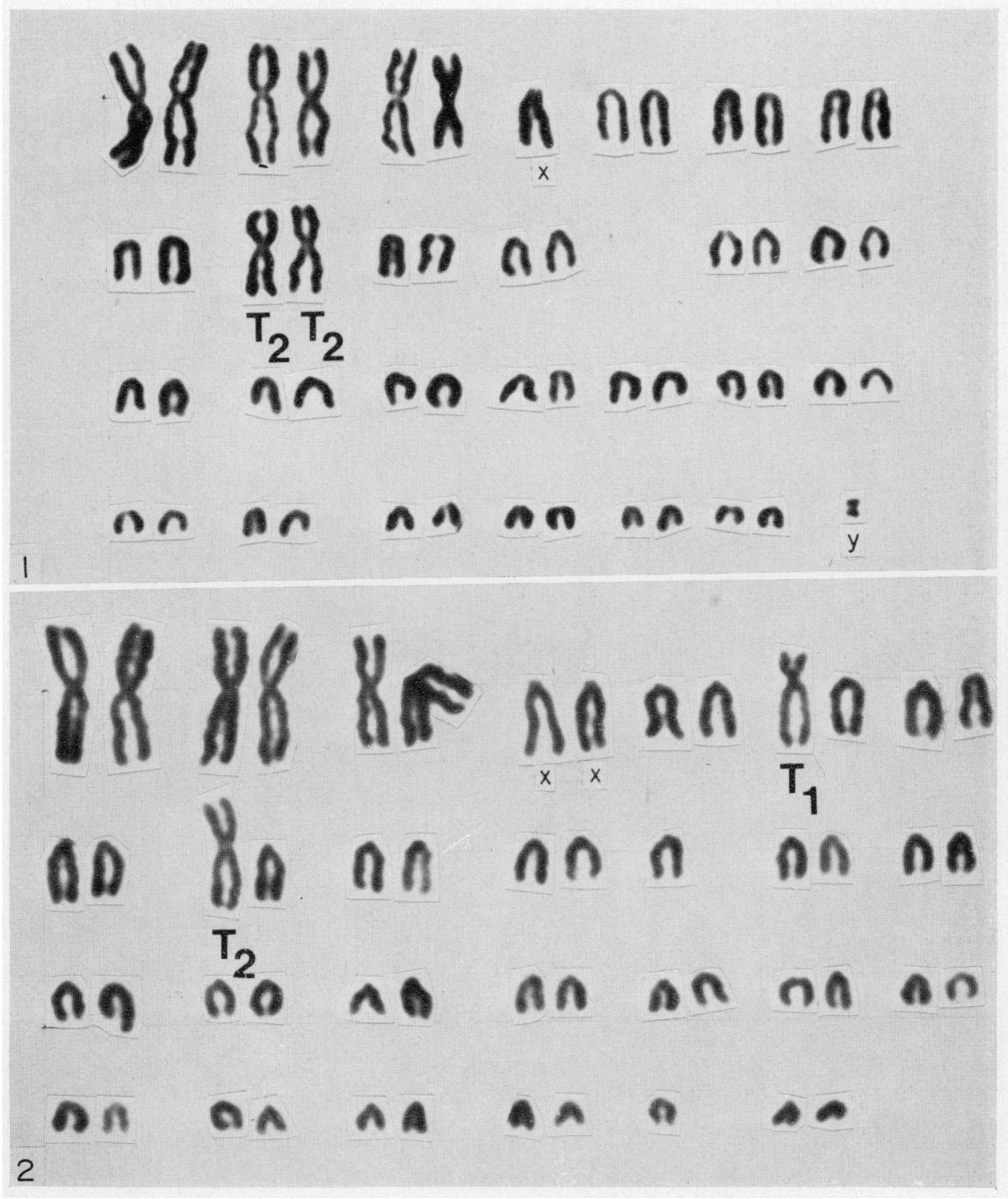

Fig. 1. The karyotype of a 52,xy, $\mathrm{t}_{2} \mathrm{t}_{2} \mathrm{ram}$. Stained with Giemsa. $\times 2000$.

FrG. 2. The karyotype of a $52, x x, t_{1} t_{2}$ ewe. Stained with Giemsa. $\times 2000$. 
normal and fertile. In addition, two further examples of double translocation heterozygotes were produced, $52, \mathrm{xy}, \mathrm{t}_{1} \mathrm{t}_{2}, 52, \mathrm{xx}, \mathrm{t}_{1} \mathrm{t}_{2}$ (Pl. 1, Fig. 2) and $52, \mathrm{xx}, \mathrm{t}_{2} \mathrm{t}_{3}$. A $52, x y, t_{1} t_{3}$ ram has been described previously as normal and fertile (Bruère \& Chapman, 1974).

\section{DISCUSSION}

All three Robertsonian translocations studied here were familial and sheep bearing them were capable of mating both with sheep carrying the normal chromosome number and with other translocation-bearing sheep.

Although a significantly high level of aneuploidy has been demonstrated in the secondary spermatocytes of all three Massey translocation heterozygous rams (Chapman, 1974; H. M. Chapman and A. N. Bruère, unpublished), the segregation data derived from the progeny conforms to a pattern of regular alternate segregation. This would suggest that the mating of $53, \mathrm{xy}, \mathrm{t} \times 54, \mathrm{xx}$ does not, in sheep, produce zygotic aneuploidy as has been reported in multiple translocation heterozygotes of the tobacco mouse (Mus poschiavinus) (Doring, Gropp \& Tettenborn, 1972; Cattanach \& Moseley, 1973; C. E. Ford and E. P. Evans, personal communication). This conclusion is also confirmed by the comparable lambing percentages from $53, \mathrm{xy}, \mathrm{t} \times 54, \mathrm{xx}$ matings and the fact that no increased return to service was noted in any of these matings. The ewes of the mating types shown in Tables 2(a) and 2(b) lambed in a regular pattern and between 78.95 and $89.24 \%$ lambed to a single service. Equivalent national data record that $78.8 \%$ of New Zealand Romney ewes lamb to a single service (Quinlivan \& Martin, 1971b).

The aneuploid secondary spermatocytes of the 53,xy,t rams apparently degenerate before spermatogenesis is complete. Roosen-Runge (1973) has suggested that cell loss in spermatogenesis is species-specific and that chromosomally abnormal cells become abortive gametes which are removed from the developing cell population before full maturation by a mechanism of negative selection. This latter concept would appear most acceptable in the ram and is different from that in the tobacco mouse in which aneuploid or chromosomally abnormal cells survive in large numbers to fertilize.

Although significant differences in male translocation progeny (Table 2a) and female translocation progeny (Table $2 \mathrm{~b}$ ) were recorded on one occasion, the overall data conform to the expected ratios of translocation versus normal progeny. From the present data, therefore, there is no overall evidence of meiotic drive (Zimmering, Sandler \& Nicoletti, 1970), a suggestion which has been proposed for the establishment of Robertsonian translocations within a population (Hamerton, 1968). The number of sheep produced bearing either $t_{1}$ or $t_{2}$, once the translocations have become established within a sheep population, would be a chance phenomenon depending on the selection of breeding animals, particularly rams. Because of testicular defects, however, there could be selection against some rams bearing the $t_{1}$ translocation (Bruère \& Mills, 1971).

The increase in male heterozygotes over normal males (Table 2a) in the 1971 mating is an interesting observation. An unequal recovery of translocation 
mice was similarly reported by Evans, Lyon \& Daglish (1967), but no explanation of this phenomenon was given. More recently, Beatty (1971) has shown that with few exceptions the phenotypic properties of Drosophila spermatozoa are determined by the diploid genome of the male that produces them and are not modified by gene expression during the haplophase of the gametogenic cycle. Ford (1971) has presented data for the mouse which are consistent with the assumption that spermatozoa take part in fertilization in numbers which are proportional to their production, regardless of a balanced or an unbalanced genome. This conclusion makes it hard to accept that spermatozoa in the sheep which carry both $\mathrm{y}$ and $\mathrm{t}$ chromosomes automatically have a preferential ability to fertilize. The finding by Beatty (1971), however, suggests that there may be between-sire differences in ability to confer preferential fertilization on t-bearing spermatozoa. This point is perhaps supported by the fact that in 1969 and 1970 the same ram was used in this study but in 1971, two different rams were used for mating (Table 2a). The limited data presented by Bruère \& Chapman (1974) using a 52, $\mathrm{xy}, \mathrm{t}_{1} \mathrm{t}_{3}$ ram, and showing an unequal recovery of $52, x y, t_{1} t_{3}$ progeny, could be interpreted in a similar manner.

The reduced lambing performance of the translocation $\times$ translocation matings compared with the translocation $\times$ normal ewe matings in the present data is due to the increased number of dry ewes in the former group. Factors which could have contributed to or caused this difference were the effect of inbreeding, the age of ewes mated, and aneuploidy of ova resulting in either zygote or embryo loss. Although some of the $1971 \mathrm{t}_{1}$ matings were father $x$ daughter matings and some of the 1972 and 1973 were half-sib matings (Table $6 \mathrm{a}$ ), these were not considered untoward levels of inbreeding (Wright's coefficient $=0.25$ and $0 \cdot 125$, respectively). Such levels are known to occur occasionally in the sheep and cattle industry (A. L. Rae, personal communication). Further, the limited data on the effects of inbreeding on the reproductive rate in sheep suggest that, besides significantly affecting the number of lambs born (inversely proportional to the number of dry ewes), inbreeding significantly affects the survival rate to weaning (Doney 1957, 1958, 1966; Lax \& Brown, 1968; Turner, 1969). The latter effect was not seen in the translocation $x$ translocation matings and the rams and ewes tested as mating in Tables $6(\mathrm{~b})$ and $6(\mathrm{e})$ were unrelated.

A factor which probably influenced the results of these matings was the age composition of the ewes (Table 8 ). In all the translocation $\times$ normal ewe matings, the ewes were mature (4 years of age or older) whereas in the translocation $x$ translocation matings, higher proportions of 18-month-old and $2 \frac{1}{2}$-year-old ewes were used except for those indicated in Table $8(\mathrm{~b})$.

The limited data from the translocation $\times$ translocation matings suggest that the reduced fertility could be attributed to the translocation ewes. Individual translocation ewes returned to service at each oestrous cycle, some on five occasions. Others did not return to service even though they were not 'in lamb'. Some ewes which were dry in one season produced twins in the following season. A likely explanation for the apparent reduced fertility of individual translocation ewes is that they produce a proportion of aneuploid gametes which in some instances mature to ova. These are fertilized but the unbalanced 
zygote is lost. The present observations on sheep could be complementary to those of Gustavsson (1969) for cattle. Gustavsson (1969) has produced limited statistical evidence suggesting that the daughters of translocation-bearing bulls of the Swedish red breed show an increased return to service due to an increased level of zygotic aneuploidy.

On the limited evidence available, the elimination of cattle and sheep which are translocation carriers is premature. More information is needed on larger groups of animals before the fertility effects of Robertsonian translocations can be completely defined. Because of the slow reproductive rate of our domestic species, such information will take time to compile, but could be rewarding since present evidence suggests that Robertsonian translocations and possibly other types of translocations are common in domestic animals (Bruère, 1974). Further, while analogies between species are frequently enlightening, the anticipated comparative effect of aneuploid gametes and embryonic loss described in the tobacco mouse (Cattanach \& Moseley, 1973) are not evident in the present data nor in the limited data on sheep that are double translocation heterozygotes (Bruère \& Chapman, 1974). This emphasizes the importance of investigating the chromosomal anomalies of each species separately.

\section{ACKNOWLEDGMENTS}

This work was supported by a grant from the Wellcome Trust of Great Britain. The author gratefully acknowledges the advice of Professor A. L. Rae of the Sheep Husbandry Department and his assistance with the analysis of data. $\mathrm{He}$ also wishes to thank Mr P. H. Whitehead and Mr W. M. Deighton for management and assistance with the sheep, Miss R. Morris and Mrs B. Bruère for technical assistance, and Mr Richard, Mr Stuart and Mr Andrew Bruère for willing assistance during five lambing seasons and on other occasions. Mrs J. Pearce typed the manuscript.

\section{REFERENCES}

BEATTY, R. A. (1971) The genetics of size and shape of spermatozoan organelles. In The Genetics of the Spermatozoon, pp. 97-115. Eds. R. A. Beatty and S. Gluecksohn-Waelsch. Edinburgh.

Bruère, A. N. (1969) Male sterility and an autosomal translocation in Romney sheep. Cytogenetics, 8, 209.

Bruère, A. N. (1973) Population studies on a further familial translocation of sheep. Vet. Rec. 92, 319.

BRUĖRE, A. N. (1974) The discovery and biological consequences of some important chromosome abnormalities in domestic animals. Proc. 1st Int. Congr., Genetics Applied to Animal Production, Madrid (in press).

BrUÈRe, A. N. \& ChAPMAN, H. M. (1974) Double translocation heterozygosity and normal fertility in domestic sheep. Cytogenet. Cell Genet. (in press).

Bruère, A. N., Chapman, H. M. \& Wyllie, D. R. (1972) Chromosome polymorphism and its possible implications in the select Drysdale breed of sheep. Cytogenetics, 11, 233.

BRUÈRe, A. N. \& McLARrN, R. D. (1967) The idiogram of the sheep with particular reference to secondary constrictions. Canad. 7. Genet. Cytol. 9, 543.

BRUÈRE, A. N. \& Milss, R. A. (1971) Observations on the incidence of Robertsonian translocations and associated testicular changes in a flock of New Zealand Romney sheep. Cytogenetics, 10, 260.

BruÈre, A. N., Zartman, D. L. \& Ghapman, H. M. (1974) The significance of the G-bands and Gbands on three different Robertsonian translocations of domestic sheep (Ovis aries). Cytogenet. Cell Genet. (in press). 
Cattanach, B. M. \& Moseley, H. (1973) Nondisjunction and reduced fertility caused by the tobacco mouse metacentric chromosomes. Cytogenet. Cell Genet. 12, 264.

Ghapman, H. M. (1974) Some aspects of meiosis in normal and Robertsonian-translocation-carrying rams. Ph.D. thesis, Massey University.

Doney, J. (1957) Effects of inbreeding on four families of Peppin Merinos. Aust. F. agric. Res, 8, 299.

DONEY, J. (1958) Effects of inbreeding on four families of Peppin Merinos. II. The influence of inbreeding on age trends. Aust. F. agric. Res. 9, 252.

Doney, J. (1966) Inbreeding depression in grazing blackface sheep. Anim. Prod. 8, 261.

Doring, L., Gropp, A. \& Tetrenborn, U. (1972) DNA content and morphological properties of presumably aneuploid spermatozoa of tobacco mouse hybrids. F. Reprod. Fert. 30, 335.

Evans, E. P., Lyon, M. F. \& Daglish, M. A. (1967) A mouse translocation giving a metacentric marker chromosome. Cytogenetics, 6, 105.

Ford, C. E. (1971) Gross genome unbalance in mouse spermatozoa: does it influence the capacity to fertilize? In The Genetics of the Spermatozoon, pp. 359-369. Eds. R. A. Beatty and S. GluecksohnWaelsch. Edinburgh.

Gustavsson, I. (1969) Cytogenetics, distribution and phenotypic effects of a translocation in Swedish cattle. Hereditas, 63, 68.

Hamerton, J. L. (1968) Robertsonian translocations in man: evidence for prezygotic selection. Cytogenetics, 7, 260.

LAX, J. \& BROWN, G. H. (1968) The influence of maternal handicap, inbreeding, and ewe's body weight at 15-16 months of age on reproduction rate in Australian merinos. Aust. J. agric. Res. $19,433$.

The Paris Conference (1971) Standardization in Human Cytogenetics. Ed. D. Bergsma. The National Foundation-March of Dimes.

Quinlivan, T. D. \& Martin, C. A. (1971a) Survey observations on the reproductive performance of both Romney stud and commercial flocks throughout New Zealand. I. National Romney stud performance. $\mathcal{N} . \mathcal{Z}$. J. agric. Res. 14, 417.

Quintrvan, T. D. \& Martin, C. A. (1971b) Oestrous activity and lamb production in the New Zealand Romney ewe. Aust. F. agric. Res, 22, 497.

Roosen-Runge, E. G. (1973) Germinal-cell loss in normal metazoan spermatogenesis. F. Reprod. Fert. 35, 339.

Turner, H. N. (1969) Genetic improvement and reproduction rate in sheep. Anim. Breed. Abstr. 37, 545.

Zimmering, S., SANdler, L. \& Nicoletti, B. (1970) Mechanisms of meiotic drive. Review Genet. 4, 409. 